\title{
Performances and Limitations of Metal Supported Cells with Strontium Titanate based Fuel Electrode
}

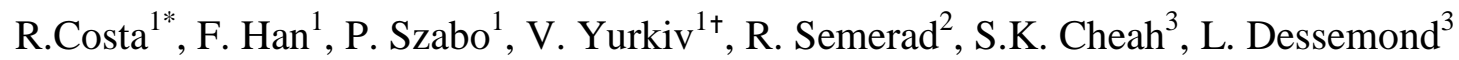

${ }^{1}$ German Aerospace Center, Institute of Engineering Thermodynamics, Pfaffenwaldring 3840, 70569 Stuttgart, Germany

${ }^{2}$ Ceraco, Ceramic Coating GmbH, Rote-Kreuz-Str. 8, D-85737 Ismaning, Germany

${ }^{3}$ Univ. Grenoble Alpes, Univ. Savoie Mont Blanc, CNRS, Grenoble INP*, LEPMI, 38000

Grenoble, France

*) Institute of Engineering Univ. Grenoble Alpes

${ }^{\dagger}$ present address: Department of Mechanical and Industrial Engineering, University of Illinois at Chicago, Chicago, Illinois 60607, USA

[*]Corresponding author: remi.costa@dlr.de

\begin{abstract}
In this contribution, we report investigation of metal supported cells with a $\mathrm{La}_{0.1} \mathrm{Sr}_{0.9} \mathrm{TiO}_{3-\alpha}$ (LST) based fuel electrode. The cells are prepared on a substrate made of a porous NiCrAl metal foam infiltrated with $\mathrm{NiO}$ and LST materials. The functional anode layer, consisting of LST mixed with a $\mathrm{Gd}_{0.1} \mathrm{Ce}_{0.9} \mathrm{O}_{2-\alpha}$ (GDC), is produced by screen printing. Nickel metal is infiltrated in the backbone to enhance electronic and catalytic properties. The electrolyte made of an $1 \mu \mathrm{m}+0.5 \mu \mathrm{m}$ thick $\mathrm{Zr}_{0.84} \mathrm{Y}_{0.16} \mathrm{O}_{2-\alpha}$ (YSZ) layer followed by a $2 \mu \mathrm{m}$ thick GDC layer, is fabricated by wet ceramic processing and Electron Beam Physical Vapor Deposition (EBPVD), respectively. $\mathrm{La}_{0.6} \mathrm{Sr}_{0.4} \mathrm{Co}_{0.2} \mathrm{Fe}_{0.8} \mathrm{O}_{3-\alpha}$ (LSCF) is employed as a cathode material. All cells are electrochemically characterized. At $750{ }^{\circ} \mathrm{C}$ and at a cell voltage of $0.7 \mathrm{~V}$, the typically achieved power density value is up to $0.40 \mathrm{~W} \mathrm{~cm}^{-2}$. With less than $2 \%$ variation for 50 cycles, the OCV showed an excellent stability as a function of redox cycles, demonstrating
\end{abstract}


that an electrolyte as thin as $3 \mu \mathrm{m}$ maintains its integrity, despite the harsh operating conditions. This highlights the potential of perovskite based fuel electrodes in metal supported cells, and paves the way to the next generation of cells' design.

Keywords: Hydrogen, Fuel Cell, Anode, Metal Supported Cell (MSC), Perovskite, Strontium Titanate, Redox Tolerant, Solid Oxide Fuel Cell, SOFC. 


\section{Introduction}

Solid Oxide Fuel Cells (SOFCs) are one of the most attractive energy conversion devices, owing to the potential of operating at high efficiency in standalone condition. SOFCs do not require noble metals for catalysis in electrodes and may use a variety of fuels including hydrocarbons, $\mathrm{CO}$ and bio-fuels, besides hydrogen. These low-noise energy convertors thus offer very high potential in stationary application and combined heat and power units (CHP) for decentralized energy. Despite all the promising advantages and the unparalleled progress in its power output, SOFC faces critical challenges in term of its poor reliability, low durability and high cost. Unless addressed meticulously, these obstacles will impede largescale commercialization of fuel cells. Reliability and durability are adversely affected by a number of factors of which the following two can be considered as the route cause: $(i)$ high operating temperatures $\left(800-1000{ }^{\circ} \mathrm{C}\right)$ of SOFC and (ii) the need to use materials that provide multiple functionalities. It includes structural support, electrochemical activity, and electrical or ionic conduction, as well as at the same time compatibility with neighboring components during the manufacturing process and fuel cell operation. This has so far made an optimization of each individual functionality impossible.

Improving the anode compartment of the SOFC can address several issues of cell degradation in static and cyclic conditions including: Ni coalescence and agglomeration, carbon and Sulphur tolerance, robustness of the cell during thermal and redox cycling [1-5]. To overcome these issues we propose to split the functionality of anode materials, thus relaxing the stringent materials demands and opening the way for these necessary improvements. A-site or B-site substituted $\mathrm{SrTiO}_{3}$ based perovskites have demonstrated high electrical conductivity after thermal treatment in reducing atmosphere, compatible thermal expansion coefficient with neighboring ceramic layers, excellent dimensional stability upon redox cycling and superior sulphur tolerance [6-8] making it a promising substitute to the state of art cermet as anode material. Nonetheless, the relatively poor mechanical property 
shown by perovskite anode materials makes difficult their implementation into anode supported cell architecture [9, 10]. In this respect, metal supported cell (MSC) architecture, where a porous metal substrate provides the mechanical strength to the thin ceramic functional layers, is especially attractive for the use of perovskite based anode materials due to its unique properties, including cost-effective material options, improved mechanical robustness, thermal shock resistance and fast start-up capability [11-13]. As disadvantages, conventional ferritic steel support materials have to be process in protection atmosphere to avoid oxidation and the diffusion of the $\mathrm{Fe}$ and other elements, for example $\mathrm{Cr}$, into the electrode material at high temperature is harmful for the long-term performance of the cell [11-12].

As a key component, a gas-tight and ionic-conductive ceramic electrolyte in an SOFC provide pathways for oxygen ions, block electrons and separate the fuel gas and air. It is favorable to equip the SOFCs in general with electrolyte as thin as possible to enhance their electrochemical performance by reducing significantly the ohmic losses [14, 15]. Nowadays, state of the art MSCs, production of thin gas tight electrolyte is made either by sintering or plasma spraying. The former process at high temperature up to $1400{ }^{\circ} \mathrm{C}$ is highly challenging [16] while the latter often result in thick electrolyte with high ASR [12]. As a mature technology, physical vapor deposition (PVD) performed at low temperature $\left(400-800{ }^{\circ} \mathrm{C}\right)$ provide an attractive option for the fabrication of hermitic thin electrolyte on metal supports avoiding processing steps at high temperature $[17,18]$.

In this work, as a progress beyond the conventional MSCs, hybrid redox stable substrates NiCrAl metal support impregnated with LST materials are developed. Full SOFCs are fabricated through a low temperature processing route, combining perovskite material based electrodes and thin film electrolyte made by PVD. The electrochemical performance of this novel type of MSC is demonstrated and investigated. 


\section{Experimental}

For this study, two types of cells, denoted as MSC type A and MSC type B are used. The MSCs type A consisted in round shape cells with a diameter of ca. $42 \mathrm{~mm}$ (30 mm diameter for the cathode), resulting in an active surface of ca. $9 \mathrm{~cm}^{2}$. The MSCs type B consisted in square cells with dimensions $50 \mathrm{~mm}$ x $50 \mathrm{~mm}$ (40 mm x $40 \mathrm{~mm}$ for the cathode), resulting in an active area of roughly $16 \mathrm{~cm}^{2}$.

\subsection{Cell manufacturing}

The Solid Oxide Cell fabricated for this study uses Ni infiltrated LST:GDC composite backbone as anode functional layer LST mixed with GDC anode functional layer, NiCrAl metal foam impregnated with $\mathrm{NiO}$ and LST materials; multi-layered YSZ/GDC electrolyte and the LSCF cathode. The processing route combines screen printing, ceramic processing and Electron Beam Physical Vapor Deposition (EB-PVD) methods as further outlines below.

\subsubsection{Substrate manufacturing}

Cell manufacturing begins with the substrate. For the cell type A, the initial powder mixture with 43 wt\% $\mathrm{La}_{0.1} \mathrm{Sr}_{0.9} \mathrm{TiO}_{3-\alpha}$ (LST) (CerPoTech, Norway) and $57 \mathrm{wt} \% \mathrm{NiO}$ (Lomberg Chemie, Germany) is milled in methyl-ethyl-ketone (MEK)/ethanol solvent for $6 \mathrm{~h}$ to form suspensions. Polyvinyl butyral (PVB, Sigma-Aldrich, Germany) and polyethylene glycol (PEG, Sigma-Aldrich, Germany) are added and mixed into to the suspensions. Homogeneous slurries are obtained after another $6 \mathrm{~h}$ milling process. NiCrAl foam (Alantum $\mathrm{GmbH}$, Germany) impregnated slurry and dried at $75{ }^{\circ} \mathrm{C}$ for $30 \mathrm{~min}$. Consequently the substrates are uni-axially pressed to increase the powder packing density and reduce the substrate thickness. For the cell type B, the same fabrication procedure applies with addition of 5-10 wt \% rice starch as pore forming agent (Remy DR, Benco, Germany) in order to increase porosity and level in the substrate. 


\subsubsection{Functional anode layer deposition}

LST powder (CerPoTech, Norway) and $\mathrm{Gd}_{0.1} \mathrm{Ce}_{0.9} \mathrm{O}_{2-\alpha}$ (GDC) powder (Treibach AG, Austria) are mixed with $\alpha$-terpineol and ethyl cellulose, and milled into an ink for anode functional layer deposition. Applying the prepared ink, anode functional layers are screen printed on the substrates, dried at $75{ }^{\circ} \mathrm{C}$ in air and fired at $1000{ }^{\circ} \mathrm{C}$ with a heating rate of $3{ }^{\circ} \mathrm{C} \mathrm{min}^{-1}$ and dwelling time of $1 \mathrm{~h}$.

\subsubsection{Electrolyte layer}

The electrolyte layer is a combination of a $\mathrm{Zr}_{0.84} \mathrm{Y}_{0.16} \mathrm{O}_{2-\alpha}$ (YSZ) nano-porous layer together with a YSZ/GDC gas tight double layer produced by physical vapor deposition (PVD). Thinfilm YSZ layer is first deposited by dip-coating of aqueous YSZ nano-suspension. The experimental details are reported elsewhere [19]. YSZ $(0.5 \mu \mathrm{m})$ and GDC $(2 \mu \mathrm{m})$ double layers are fabricated by electron beam physical vapor deposition (EB-PVD) method.

Leak rates are measured by using the pressure-rise method, where a vacuum is applied on the side with the gas tight electrolyte layer. The time until the pressure rises to ambient conditions is then measured. The leak rate is determined at a pressure difference of $100 \mathrm{mbar}$ in regard to ambient pressure which is defined as the maximum allowed pressure difference between both electrodes as a pressure difference higher than 100 mbar may cause damages to the cell in the stack. In order to compare cells with different areas such as button cells and stack size cells, an area specific leak rate is then calculated based on the sealed area.

\subsubsection{Catalytic nickel infiltration}

A concentrated aqueous solution with 70.8 wt\% of nickel nitrate $\left(\mathrm{Ni}\left(\mathrm{NO}_{3}\right)_{2}, 6 \mathrm{H}_{2} \mathrm{O}\right.$; Alfa Aesar) is infiltrated with a pipette from the back side of the half cells into the porous support and the anode functional layer. The infiltrated half cells are then calcined at $450{ }^{\circ} \mathrm{C}$ for 10 min. The infiltration cycle is repeated 3 times to obtain approx. 5 to $10 \mathrm{wt} \%$ nickel loading in the half cells. 


\subsubsection{Cathode deposition}

$\mathrm{La}_{0.6} \mathrm{Sr}_{0.4} \mathrm{Co}_{0.2} \mathrm{Fe}_{0.8} \mathrm{O}_{3-\delta}(\mathrm{LSCF})$ powder (CerPoTech, Norway) is mixed with $\alpha$-terpineol and ethyl cellulose and milled into an ink. The cathode layer is the screen printed onto the halfcells dried at $75^{\circ} \mathrm{C}$ in air before the electrochemical tests.

\subsection{Electrochemical testing}

\subsubsection{Performance and durability}

The type A MSC, containing infiltrated nickel, was tested in an open flanges set-up in radial configuration supplied by FIAXELL (Switzerland) by using gold grids $\left(640\right.$ mesh $\left.\mathrm{cm}^{-2}\right)$ as current collectors. Gold was chosen to avoid any catalytic contribution to oxidation of hydrogen. A finer platinum grid $\left(1024 \mathrm{mesh}^{-2}\right)$ was added to the cathode side to improve the current collecting since the cathode layers were not well sintered before measurements. The temperature was step-wise increased from room temperature up to the working temperature $\left(5{ }^{\circ} \mathrm{C} \mathrm{min}{ }^{-1}\right)$ in synthetic air $\left(100 \mathrm{~mL} \mathrm{~min}^{-1}\right)$ at the cathode and in dry Argon (100 $\mathrm{mL} \min ^{-1}$ ) at the anode. At the working temperature, the $\mathrm{H}_{2}$ content of the feeding gas was slowly increased at a constant gas flow rate to reach $80 \mathrm{~mL} \mathrm{~min}^{-1}$ of $\mathrm{H}_{2}$ and $20 \mathrm{~mL} \mathrm{~min}^{-1}$ of Ar. The effective reduction of the anode was checked by measuring the open circuit voltage (OCV) value of the cell. In the chosen experimental conditions, the OCV values were lower than the theoretical ones, even if the leak rate of the electrolyte membrane was low. This is likely to originate from the open atmosphere of the testing set-up causing water vapor formation at the anode side. The polarization curves were recorded in potentiostatic conditions and impedance measurements were performed at $\mathrm{OCV}$ for frequencies varying between $10^{4} \mathrm{~Hz}$ and $10^{-2} \mathrm{~Hz}$ using an $\mathrm{AC}$ signal equal to $50 \mathrm{mV}$ at $757^{\circ} \mathrm{C}$ in dry $\mathrm{H}_{2} / \mathrm{Ar}$ at the anode side and air at the cathode side. The electrochemical properties were determined using an Autolab potentiostat-galvanostat (PGSTAT 302N) coupled with a current booster. The 
impedance data were processed with the ZView ${ }^{\circledR}$ software (Scribner Associates). All results are normalized to the cathode area. The effect of current load on the performance of the type A MSC was recorded by polarizing the cell twice at constant current corresponding to the maximum power density (MPD) in $\mathrm{H}_{2} / \mathrm{Ar}$ at the anode side and air at the anode side: $0.81 \mathrm{~A}$ $\mathrm{cm}^{-2}$ for $431 \mathrm{~h}$ (step 1) and $0.40 \mathrm{~A} \mathrm{~cm}^{-2}$ for $505 \mathrm{~h}$ (step 4). Between those two steps, the cell was cooled down to room temperature under an argon atmosphere $\left(2 \mathrm{~K} \mathrm{~min}^{-1}\right)$, due to a failure of power supply of the experimental set-up. The cell was then heated up to $757^{\circ} \mathrm{C}\left(2 \mathrm{~K} \mathrm{~min}^{-1}\right)$ still in Ar. This cooling-heating process was regarded as one thermal cycle (step 2). Capability of the cell to withstand such event is also a factor of performance [20]. After step 2, since preliminary measurements on single cells based on nickel-containing $\mathrm{NiCrAl}$ foam showed that the power density increased slightly with time (for $160 \mathrm{~h}$ ) during isothermal ageing at $757{ }^{\circ} \mathrm{C}$ in dry hydrogen at $\mathrm{OCV}$, an isothermal treatment was performed at $\mathrm{OCV}$ at $757^{\circ} \mathrm{C}$ in dry argon for $456 \mathrm{~h}$ (step 3 ). No forced redox cycle was performed.

\subsubsection{Tolerance towards redox cycles}

The type B MSC, with pore forming agent in the substrate and infiltrated catalytic nickel was tested against redox cycles in co-flow configuration. The cell was mounted in a twoatmosphere chamber, using gold sealing. Anode was contacted with a coarse nickel mesh (1024 mesh $\left.\mathrm{cm}^{-2}\right)$, while cathode was contacted with a fine Pt mesh $\left(3600 \mathrm{mesh}^{-2}\right)$. The effective contacted area was $16 \mathrm{~cm}^{2}$.

The cell is first heated from room temperature to working temperature $\left(750{ }^{\circ} \mathrm{C}\right)$ at $3{ }^{\circ} \mathrm{C} \mathrm{min}^{-1}$ with Ar gas at the anode and air at the cathode side. The cell was then dwelled for $1 \mathrm{~h}$ with $1 \mathrm{~L} \mathrm{~min}^{-1}$ of $\mathrm{Ar}-5$ vol $\% \mathrm{H}_{2}$ at the anode and $1 \mathrm{~L} \mathrm{~min}^{-1}$ of air at the cathode. For activating the anode, $\mathrm{H}_{2}$ concentration was increased in steps up to $50 \%$ before supplying pure hydrogen. The cell is then let at OCV for about $100 \mathrm{~h}$ in order to stabilize the microstructure at operating condition. $1 \mathrm{~L} \mathrm{~min}^{-1}$ of $\mathrm{H}_{2}$ with $3 \%$ of $\mathrm{H}_{2} \mathrm{O}$ was used at the anode while $1 \mathrm{~L}$ 
$\min ^{-1}$ of air was flushed over the cathode. Redox cycles are performed in isothermal conditions. At working temperature, the hydrogen supplied is first stopped and the anode is flushed for 5 min with $1 \mathrm{~L} \mathrm{~min}^{-1}$ of $\mathrm{N}_{2}$, to induce heterogeneous oxidation of the anode with the ionic current originating from the cathode. As oxidation at low $\mathrm{pO}_{2}$ is limited by oxygen diffusion and results only in a partial oxidation of the extreme surface of the material, confined nearby the interface with the electrolyte, a second oxidation step at high $\mathrm{pO}_{2}$ is performed to overcome any limitation due to poor oxygen diffusion within the porous structure [21]. $1 \mathrm{~L} \mathrm{~min}^{-1}$ of pure $\mathrm{O}_{2}$ was supplied to the anode for at least $30 \mathrm{~min}$ in order to induce homogeneous oxidation of the material, and thus a larger expansion. After $30 \mathrm{~min}$ exposure to oxygen gas, re-oxidation was considered to be completed, and the anode was flushed again for 5 min with $1 \mathrm{~L} \mathrm{~min}^{-1}$ of $\mathrm{N}_{2}$ in order to remove traces of oxygen gas in the test set-up and in the anode before feeding again the cell with $1 \mathrm{~L} \mathrm{~min}^{-1}$ of $\mathrm{H}_{2}$ with $3 \%$ of $\mathrm{H}_{2} \mathrm{O}$. The polarization curves are recorded in potentiostatic conditions between each redox cycles after voltage stabilization. After the redox cycles the microstructure of the different components of type B MSC is checked using a scanning electron microscope (SEM) Zeiss ULTRA PLUS SEM (Carl Zeiss AG, Germany).

\section{Results and Discussion}

The major objective of the present work is to evaluate the performance and durability of the novel MSCs types by performing series of electrochemical tests (e.g., polarization curves, impedances and voltage stability tests) and the robustness against redox cycles as further detailed below.

\subsection{Leak-rate and tightness}

Both types of MSCs (type A and type B), demonstrated gas tightness values in the range of $0.710^{-4} \mathrm{~Pa} \mathrm{~m}^{3} \mathrm{~s}^{-1} \mathrm{~cm}^{-2}-1.210^{-4} \mathrm{~Pa} \mathrm{~m}^{3} \mathrm{~s}^{-1} \mathrm{~cm}^{-2}$. This meets the requirements of the quality control threshold of an air leakage rate below $510^{-4} \mathrm{~Pa} \mathrm{~m}^{3} \mathrm{~s}^{-1} \mathrm{~cm}^{-2}$. This recorded value, 
despite the extremely thin electrolyte of less than $3 \mu \mathrm{m}$ in thickness, outperformed the ones recorded on cells implementing conventional vacuum plasma sprayed electrolytes with a thickness of 35-70 $\mu \mathrm{m}$ for which typical leak rate values are in the range of $1.710^{-4} \mathrm{~Pa} \mathrm{~m}^{3} \mathrm{~s}^{-1}$ $\mathrm{cm}^{-2}-15.210^{-4} \mathrm{~Pa} \mathrm{~m}^{3} \mathrm{~s}^{-1} \mathrm{~cm}^{-2}[12]$.

\subsection{Performance and degradation}

The electrochemical performance of cells was evaluated by performing polarization curves and impedance measurements of the initial cells. Figure 1 illustrates experimentally measured voltage and power density curves as functions of current density (I-V-P curves) for five steps at $757{ }^{\circ} \mathrm{C}$ in $\mathrm{H}_{2}-\mathrm{Ar}$ /Air. No limiting current density was evidenced from I-V curves (Figure 1). This suggests that the physical properties of both electrodes (e.g. porosity and pore tortuosity) as well as parameters of the experimental set-up are appropriate to avoid any masstransport limitations [22]. In the chosen experimental conditions, the cell voltage decreases linearly with increase of current density, in agreement with previous published results on single cells comprising LST-based anodes and operating between 650 and $850{ }^{\circ} \mathrm{C}$ [23-29]. The linearity of $\mathrm{I}-\mathrm{V}$ curves suggests the ohmic cell resistance to be predominant. This resistance consists of contributions from ohmic losses due to current collection, ions transfer through the electrolyte and electrode current constrictions [30]. The responses at different interfaces also contribute to these losses. In tested conditions, the initial value of power density at $0.7 \mathrm{~V}$ of type A MSC is equal to $0.281 \mathrm{~W} \mathrm{~cm}^{-2}$, with an OCV of $0.94 \mathrm{~V}$ (Figure 1).

The MPD value is of $0.363 \mathrm{~W} \mathrm{~cm}$. The performance is at an acceptable value when compared with those reported in the literature for metal-supported or ceramic-supported cells with a LST anode [31], although the performance is strongly influenced by the microstructures of both electrodes and electrolyte thickness. The initial MPD value is higher than those recorded for electrolyte-supported cells (electrolyte thickness: 500-600 $\mu \mathrm{m}$ ) comprising nickel-impregnated LST-GDC anodes in wet hydrogen at $800{ }^{\circ} \mathrm{C}\left(\sim 0.3 \mathrm{~W} \mathrm{~cm}^{-2}\right)$ $[32,33]$. A MPD value in excess of $0.08 \mathrm{~W} \mathrm{~cm}^{-2}$ at $750{ }^{\circ} \mathrm{C}$ was reported for an anode- 
supported cell (32 $\mu \mathrm{m}$ electrolyte thickness) with a GDC and Ni-impregnated LST anode [34].

For a thinner electrolyte ( $2 \mu \mathrm{m}$ thickness), a MPD value of $0.320 \mathrm{~W} \mathrm{~cm}^{-2}$ at $750{ }^{\circ} \mathrm{C}$ was reported by Lee et al. [35].

Three main contributions can be evidenced in the cell impedance, especially after degradation of the performance (Figure 2). A detailed assignment of the impedance responses of type A MSC is beyond the scope of this paper, thus all impedance diagrams were fitted using the equivalent circuit: $\mathrm{L}_{-} \mathrm{R}_{\mathrm{s}}-(\mathrm{RQ})_{\mathrm{HF}}-(\mathrm{RQ})_{\mathrm{MF}}-(\mathrm{RQ})_{\mathrm{LF}}$. In the last expression, $\mathrm{L}$ is the inductance of the set-up, $R_{\mathrm{s}}$ is the series resistance related to ohmic losses and the series connection of $(\mathrm{RQ})_{\mathrm{HF}},(\mathrm{RQ})_{\mathrm{MF}}$ and $(\mathrm{RQ})_{\mathrm{LF}}$ corresponds to the three contributions to the polarization resistance $\mathrm{R}_{\mathrm{p}}$ at high (HF), medium (MF) and low (LF) frequencies, respectively. For each arc, $\mathrm{R}$ is the resistance and $\mathrm{Q}$ the corresponding constant phase element. The high frequency intercept of the cell impedance on the real axis represents the series resistance. The polarization resistance is derived from the difference between the low frequency intercept of the cell impedance on the real axis and $R_{s}$. The chosen electrical equivalent circuit is in rather well agreement with literature reports. At least two main responses were observed in the single cell impedance which may include several overlapped electrode processes (i.e. charge transfer and mass transfer) $[6,34]$. At temperatures above $650{ }^{\circ} \mathrm{C}$ in dry or wet hydrogen, the impedance of a LST-based composite anode was found to be composed by two or three contributions $[32,33,36-38]$. According to a differential impedance spectroscopy analysis, four distinct electrode processes were determined for a LST-GDC anode and a LSM-YSZ cathode deposited on a thin scandium-doped ceria stabilized zirconia electrolyte [39]. The frequency distribution of type A MSC impedance is not significantly modified during and after different steps (Figures 2 and 3), indicating that no additional significant feature contributes to this impedance. Accordingly, the chosen electrical equivalent circuit can be regarded as meaningful to describe the recorded behaviors in tested conditions. 
The initial performance observed in Figure 1 is related to series $\left(R_{s}\right)$ and polarization $\left(R_{p}\right)$ resistances as low as $0.46 \Omega \mathrm{cm}^{2}$ and $0.11 \Omega \mathrm{cm}^{2}$ (Figure 2). The HF, MF and LF resistances are equal to $0.02 \Omega \mathrm{cm}^{2}, 0.04 \Omega \mathrm{cm}^{2}$ and $0.05 \Omega \mathrm{cm}^{2}$, respectively. The obtained series resistance is higher than expected for the effective multi-layered electrolyte thickness. A series resistance of $0.60 \Omega \mathrm{cm}^{2}$ was determined at $750{ }^{\circ} \mathrm{C}$ for a metal-supported cell comprising a Ni-impregnated LST-GDC composite anode deposited on a completely dense YSZ electrolyte layer $(\sim 1.5 \mu \mathrm{m})$ [35]. This value was related to the thickness of the anode functional layer. At this stage, one can infer that current constrictions and current collection significantly contribute to ohmic losses of type A MSC since a green LSCF cathode was used $[40,41]$. It is worth noting that the apex frequency of HF contribution $\left(\sim 710^{2} \mathrm{~Hz}\right.$ at $\left.757^{\circ} \mathrm{C}\right)$ is in agreement with values determined for Ni-GDC infiltrated LST anodes at $750{ }^{\circ} \mathrm{C}$ in wet hydrogen at OCV [37]. According to an elementary kinetic model developed for LST-based anodes [42], this contribution corresponds to an ionic exchange step at the anode. The apex frequency of LF contribution $\left(\sim 0.5 \mathrm{~Hz}\right.$ at $\left.757^{\circ} \mathrm{C}\right)$ is close to that obtained for an anode-supported cell by Savaniu et al. [34]. These authors suggest that this response could be related to mass transfer at the electrodes. During operation at $0.8 \mathrm{~A} \mathrm{~cm}^{-2}$ (step 1), the cell voltage decreases with operating time (Figure 3). Though a transient increase of cell voltage is recorded during the current interruption to perform impedance measurements at $\mathrm{OCV}$, a monotonic increase of both $R_{s}$ and $R_{p}$ is evidenced during the whole period (Figure 4). This explains the decline of cell performance during $431 \mathrm{~h}$ of operation (Figure 1). The OCV, power density at $0.7 \mathrm{~V}$ and MPD are equal to $0.89 \mathrm{~V}, 0.178 \mathrm{~W} \mathrm{~cm}^{-2}$ and $0.240 \mathrm{~W} \mathrm{~cm}^{-2}$, respectively. The recorded degradation can be related to the main increase of the polarization resistance at OCV (Figure 2). $R_{s}$ is then equal to $0.50 \Omega \mathrm{cm}^{2}$ while $R_{p}$ increases up to $0.37 \Omega$ $\mathrm{cm}^{2}$ because of the highest variation of the HF resistance $\left(\mathrm{R}_{\mathrm{HF}}=0.25 \Omega \mathrm{cm}^{2}, \mathrm{R}_{\mathrm{MF}}=0.06 \Omega\right.$ $\mathrm{cm}^{2}, \mathrm{R}_{\mathrm{LF}}=0.06 \Omega \mathrm{cm}^{2}$ ). Although a partial sintering of the LSCF cathode should be 
anticipated during the treatment, the magnitude of ohmic losses is enhanced. An increasing series resistance yields a higher slope of the I-V curve (Figure 1). No degradation of the performance of a metal-supported SOFC was obtained during operation under $0.2 \mathrm{~A} \mathrm{~cm}^{-2}$ for $1000 \mathrm{~h}$ at $600{ }^{\circ} \mathrm{C}$ because the microstructure of the infiltrated anode showed no significant variation [35]. On the other hand, the MPD of a stainless steel-supported SOFC declined after operation at $\mathrm{OCV}$ for $60 \mathrm{~h}$ at $650{ }^{\circ} \mathrm{C}$ [43]. The observed decrease was mainly related to an OCV drop suggesting that the electrolyte layer started to crack yielding an increasing polarization resistance and a constant series resistance. For type A MSC, the OCV remains nearly constant and the occurrence of fatal cracks in the multi-layered electrolyte is unlikely. The lower performance can be due to a degradation of oxygen transport through the cell [42]. An argument in favor of this assumption is that the degradation of the electrode/electrolyte interface (without any additional insulating phases) results predominantly in an increase of the polarization resistance without any modification of the frequency distribution of the cell impedance [44]. Indeed, additional insulating phases should alter this frequency distribution [45].

The performance decrease is smaller after a thermal cycle between $757{ }^{\circ} \mathrm{C}$ and room temperature (step 2) (Figure 1). The OCV remains nearly unchanged $(0.90 \mathrm{~V})$, the power density at $0.7 \mathrm{~V}$ is $0.128 \mathrm{~W} \mathrm{~cm}^{-2}$ and the MPD is of $0.190 \mathrm{~W} \mathrm{~cm} \mathrm{~cm}^{-2}$. At $\mathrm{OCV}$, the degradation is related to an increase of series $\left(\mathrm{R}_{\mathrm{s}}=0.59 \Omega \mathrm{cm}^{2}\right)$ and polarization $\left(\mathrm{R}_{\mathrm{p}}=0.46 \Omega \mathrm{cm}^{2}\right)$ resistances. Both $R_{M F}$ and $R_{L F}$ remain unchanged and $R_{H F}$ rises up to $0.34 \Omega \mathrm{cm}^{2}$. The higher series resistance results in a higher slope of the I-V curve. Previously published reports have shown that LST-GDC-Ni anodes exhibited a good thermal stability (i.e. no performance degradation) after successive thermal cycles from the operating temperature of $700{ }^{\circ} \mathrm{C}$ or 900 ${ }^{\circ} \mathrm{C}$ down to $550{ }^{\circ} \mathrm{C}$ or $700{ }^{\circ} \mathrm{C}$, respectively $[29,46]$. Nevertheless, a direct comparison of cell degradation or cell stability during thermal cycling is difficult due to differences in experimental parameters including heating-cooling rates, temperature range or number of 
thermal cycles. Indeed, the polarization resistance was shown to decrease for 50 cycles between 600 and $170{ }^{\circ} \mathrm{C}$, but it increased during subsequent 50 cycles leading globally to a decrease of MPD [47]. The decline was mainly related to the cathode degradation. Since $\mathrm{R}_{\mathrm{s}}$ and $\mathrm{R}_{\mathrm{HF}}$ exhibit the main variations, the recorded degradation can be due to a further alteration of current collecting during step 2.

After an isothermal ageing at OCV for $456 \mathrm{~h}$ in argon (step 3), no significant degradation of performance is evidenced at $757^{\circ} \mathrm{C}$ (Figure 1). Indeed, the series resistance slightly decreases $\left(\mathrm{R}_{\mathrm{s}}=0.57 \Omega \mathrm{cm}^{2}\right)$ and the polarization resistance increases only by a factor $1.2\left(\mathrm{R}_{\mathrm{p}}=0.54 \Omega\right.$ $\mathrm{cm}^{2}$ ). This suggests that the anode atmosphere should also affect the magnitude of the ageing effect.

Another operating period under a current load $\left(0.4 \mathrm{~A} \mathrm{~cm}^{-2}\right.$ for $505 \mathrm{~h}$, step 4) yield an increase of cell impedance (Figure 4) and a degradation of cell performance (Figure 1), as could be expected from the results recorded after step 1 . The power density at $0.7 \mathrm{~V}$ and OCV are found equal to $0.057 \mathrm{~W} \mathrm{~cm}^{-2}$ and $0.80 \mathrm{~V}$, respectively and the MPD is of $0.116 \mathrm{~W} \mathrm{~cm}^{-2}$. As during step 1, a transient increase of cell voltage is observed during the current interruption to perform impedance measurements but an average monotonic decrease is recorded for $505 \mathrm{~h}$ (Figure 3). The degradation originates mainly from the polarization resistance (from 0.54 to $\left.0.84 \Omega \mathrm{cm}^{2}\right)$ since the series resistance can be regarded as unchanged $\left(\mathrm{R}_{\mathrm{s}}=0.56 \Omega \mathrm{cm}^{2}\right)$ (Figure 2). It is worth mentioning that the magnitude of degradation rises with applied current. Indeed, the total cell resistance $\left(R_{s}+R_{p}\right)$ increases by a factor of 1.5 and 1.3 after operating at $0.81 \mathrm{~A} \mathrm{~cm}^{-2}$ (step 1) and $0.40 \mathrm{~A} \mathrm{~cm}^{-2}$ (step 4). As for previous treatments, the HF resistance increases after step $4\left(\mathrm{R}_{\mathrm{HF}}=0.50 \Omega \mathrm{cm}^{2}\right)$ but the highest degradation is recorded for the MF contribution (apex frequency $\sim 60 \mathrm{~Hz}$ at $757^{\circ} \mathrm{C}$ ). $\mathrm{R}_{\mathrm{MF}}$ rises from $0.11 \Omega \mathrm{cm}^{2}$ up to $0.23 \Omega \mathrm{cm}^{2}$ at $\mathrm{OCV}$. The middle frequency arc can be due to the cathode contribution $[48,49]$ since the corresponding apex frequency was reported to be $\sim 50 \mathrm{~Hz}$ at about $750{ }^{\circ} \mathrm{C}[50,51]$. However, this process may overlap with a charge transfer reaction at LST - Ni interface [52]. 
Respect to microstructure, one may link the degradation of MF contribution with an agglomeration of $\mathrm{Ni}$ particles, yielding a performance degradation of Ni-infiltrated LST electrodes $[34,53]$. However, a decline of current collecting performance is to expect, while the series resistance is not affected in the chosen conditions. Therefore, a Ni particle agglomeration is unlikely to explain the observed behavior of the MF contribution. The recorded increase can be thus related with a degradation of the oxygen reduction process. It is worth mentioning that a partial delamination of LSCF is not in contradiction with the increase of $\mathrm{HF}$ resistance.

The OCV drop after step 4 may suggest an increased leakage between the anode and cathode compartments. One may hypothesize appearance of cracks in the double layer electrolyte [43]. Though, visual inspection of the cell after test could not evidence a massive cracking, initiation and propagation of cracks at the pinhole defects, due to thermo-mechanical stresses induced by the leakage and the burning of the fuel cannot be excluded. Thus the exact origin of this OCV drop remains unclear and further detailed post mortem microstructural analysis would be required in order to elucidate this. Regardless the magnitude of the decline of performance, a striking result is that the investigated cell is still working after $1392 \mathrm{~h}$ of isothermal ageing. This suggests that the robustness of the cell is improved with a double electrolyte layer [19].

\subsection{Redox Tolerance}

At $750{ }^{\circ} \mathrm{C}$, the initial values of OCV for type B MSC are equal to $1.01 \mathrm{~V}$ (Figure 5) while the power density measured at $0,7 \mathrm{~V}$ equals to $0.275 \mathrm{~W} \mathrm{~cm}^{-2}$ (Figure6). These performances are related to series and polarization resistances as low as $0.58 \Omega \mathrm{cm}^{2}$ and $0.25 \Omega \mathrm{cm}^{2}$ (not shown here). The recorded enhancement can be regarded roughly as an increasing function of the number of redox cycles, at least up to 20 cycles (Figure 6). At $0.7 \mathrm{~V}$, the maximum power density is $0.440 \mathrm{~W} \mathrm{~cm}^{-2}$ at $750{ }^{\circ} \mathrm{C}$. This is mainly due to the decrease of the series resistance 
by a factor 1.9 while the polarization resistance only slightly increased by $10 \%$ (not shown here). At this stage, the observed increase of the power density could be related to a deagglomeration step of nickel particles enhancing the current collecting. It is worth noting that both OCV and power density decrease after an overnight isothermal ageing, in rather well agreement with results recorded during isothermal ageing.

Regardless of the cell voltage, a monotonic decrease of the power density is recorded beyond 30 redox cycles (Figure 6). Nevertheless, the power density remains higher than its initial value after 54 redox cycles. Such a decrease can be related to a partial delamination of the interface between the anode substrate and the anode functional layer (Figure 7). The observed cracks are likely to originate from the repeated volume variations between nickel and nickel oxide. The OCV shows an excellent stability as a function of redox cycles (Figure 6), which demonstrates that a thin film electrolyte maintains integrity despite the harsh conditions.

The performances of type B MSC were compared to those of a commercial Anode Supported Cell (ASC) supplied by Ceramtec GmbH (Germany) as functions of redox cycles performed in similar experimental conditions. While the initial power density of the ASC is higher than that of type B MSC (Figure 6), the related performances are significantly altered after 4 successive redox cycles and the corresponding OCV decreases (Figure 5) and dropped below $0.9 \mathrm{~V}$ suggesting increased leakage through the electrolyte likely being due to appearance of cracks. At $750{ }^{\circ} \mathrm{C}$, the power density decreases by $60 \%$ and $70 \%$ at $0.7 \mathrm{~V}$ and $0.8 \mathrm{~V}$, respectively (Figure 6). At $0.7 \mathrm{~V}$, the power density is only slightly higher than that recorded for type B cell after 54 cycles. For this latter cell, the power density decreases only by $30 \%$ at $0.7 \mathrm{~V}$. It is worth noting that the measurements lasted around $350 \mathrm{~h}$ at $750{ }^{\circ} \mathrm{C}$. These results demonstrate the stability of the chosen anode materials and further confirm the robustness of the architecture in comparison with the main stream ASCs implementing a standard Ni-YSZ cermet. 


\section{Conclusions}

Advanced metal foam supported cells, with LST based functional anode layer, are produced and demonstrated successfully. A set of polarization curves, electrochemical impedances and voltage stability tests measurements is carried out, seeking to evaluate performance and durability of the cells. It is found that with addition of nickel to the current collector - for enhancing the electronic conductivity - and to the functional anode layer - for enhancing the electro-catalytic behavior - a power density of $0.340 \mathrm{~W} \mathrm{~cm}^{-2}$ at $750{ }^{\circ} \mathrm{C}$ and $0.7 \mathrm{~V}$ can be achieved. Further modification of the substrate, consisting in increasing its porosity by addition of pore forming agent, leads to an increase of power density up to $0.440 \mathrm{~W} \mathrm{~cm}^{-2}$ at $750{ }^{\circ} \mathrm{C}$ and $0.7 \mathrm{~V}$. The implementation of a $0.5 \mu \mathrm{m}$ thick yttria stabilized zirconia layer, by PVD in the multi layered structure of the electrolyte, positively impacts the OCV of the cell, its durability and performance. The precise quantification of the YSZ addition impact on OCV values remains, nonetheless, difficult to accurately quantify as this parameter still remains highly sensitive to density of defects in the electrolyte. The progressive increase of the resistance of the ionic transport in the electrolyte and the cathode compartment is found to be the major source of degradation of the cell, which provides qualitative insights regarding the potential durability of a perovskite based anode material. With less than $2 \%$ variation for 50 cycles, the OCV showed an excellent stability as a function of redox cycles, demonstrating that an electrolyte as thin as $3 \mu \mathrm{m}$ maintains its integrity, despite the harsh operating conditions. The present results show that a thin electrolyte based SOC system is certainly feasible. Those results demonstrate the robustness of this design compared to main stream Anode Supported Cells. In addition our findings deliver useful quantitative and qualitative insights concerning operating conditions and rate-limiting steps that can ascertain valuable SOC based technology development for a wide range of application.

\section{Acknowledgements}


This work was funded by the European Union's Seventh Framework Programme (FP7/20072013) for the Fuel Cells and Hydrogen Joint Technology Initiative under grant agreement $\mathrm{n}^{\circ} 303429$.

\section{References}

[1] H. Tu, U. Stimming, J. Power Sources, 2004, 127, 284

[2] S. McIntosh, R.J. Gorte, Chem. Rev., 2004, 104, 4845

[3] S. Zha, Z. Cheng, M. Liu, J. Electrochemical Soc., 2007, 154, B201

[4] D. Sarantaridis, A. Atkinson, Fuel Cells, 2007, 7, 246

[5] A. Faes, A. Nakajo, A. Hessler-Wyser, D. Dubois, A. Brisse, S. Modena, J. Van herle, J. Power Sources, 2009, 193, 55

[6] C.D. Savaniu, J.T.S. Irvine, Solid State Ionics, 2011, 192, 491

[7] Q. Ma, F. Tietz, Solid State Ionics, 2012, 225, 108

[8] N. Yan, S. Zanna, L. H. Klein, M. Roushanafshar, B. S. Amirkhiz, Y. Zeng, G. Rothenberg, P. Marcus, J.-L. Luo, J. of Power Sources, 2017, 343, 127

[9] S. Veltzé, B.R. Sudireddy, P.S. Jørgensen, W. Zhang, L.T. Kuhn, P. Holtappels, T. Ramos, ECS Trans., 2013, 57, 743

[10] P. Holtappels, J.T.S. Irvine, B. Iwanschitz, L.T. Kuhn, L.Y. Lu, Q. Ma, J. Malzbender, A. Mai, T. Ramos, J. Rass-Hansen, B.R. Sudireddy, F. Tietz, V. Vasechko, S. Veltzé, M.C. Verbracken, ECS Trans., 2013, 57, 1175

[11] M. C. Tucker, G. Y. Lau, C. P. Jacobson, L. C. DeJonghe, S. J. Visco, J. Power Sources, 2007, 171, 477

[12] P. Szabo, J. Arnold, T. Franco, M. Gindrat, A. Refke, A. Zagst, A. Ansar, ECS Trans., 2009, 25, 175

[13] M. C. Tucker, J. Power Sources, 2010, 195, 4570

[14] T. Van Gestel, F. Han, D. Sebold, H. P. Buchkremer, D. Stöver, Microsystem Technologies, 2011, 17-2, 233 
[15] F. Han, R. Mücke, T. Van Gestel, A. Leonide, N. H. Menzler, H. P.Buchkremer, D.

Stöver, J. Power Sources, 2012, 218, 157

[16] S. Vieweger, R. Mücke, N. H. Menzler, H. P. Buchkremer, Fuel Cells, 2013, 13, 556

[17] R. Vaßen, D. Hathiramani, J. Mertens, V.A.C. Haanappel, I.C. Vinke, Surface \&

Coatings Technology, 2007, 202, 499

[18] M. Lang, T. Franco, G. Schiller, N. Wagner, J. Applied Electrochemistry, 2002, 32, 871

[19] F. Han, R. Semerad, G. Constantin, L. Dessemond, R. Costa, ECS Trans., 2015, 68,1889

[20] J. Van Herle, D. Perednis, K. Nakamura, S. Diethelm, M. Zahid, A. Aslanides, T.

Somekawa, Y. Baba, K. Horiuchi, Y. Matsuzaki, M. Yashimoto, O. Bucheli, J. Power

Sources, 2008, 182, 389

[21] A. Faes, A. Hessler-Wyser, A. Zryd, J. Van Herle, Membranes, 2012, 2, 585

[22] L.A. Chick, K.D. Meinhardt, S.P. Simmer, B.W. Kirby, M.R. Powell, N.L. Canfield, J.

Power Sources, 2011, 196, 4475

[23] K. Ahn, S. Jang, J.M. Vohs, R.J. Gorte, Ceram. International, 2007, 33, 1065

[24] M.R. Pillai, I. Kim, D.M. Bierschenk, S.A. Barnett, J. Power Sources, 2008, 185, 1086

[25] G. Kim, M.D. Gross, W. Wang, J.M. Vohs, R.J. Gorte, J. Electrochem. Soc., 2008, 155, B360

[26] M.K. Rath, B.G. Ahn, B.H. Choi, M.J. Ji, K.T. Lee, Ceram International, 2013, 39, 6343

[27] S.L. Zhang, C.X. Li, C.J. Li, J. Power Sources, 2014, 264, 195

[28] H. Yoon, J. Zou, N.M. Sammes, J. Chung, Int. J. Hydrogen Energy, 2015, 40, 10985

[29] Q. Hu, C. Liu, L. Fan, Y. Wang, Y. Xiong, Electrochim. Acta, 2018, 265, 1

[30] J. Nielsen, A.H. Persson, B.R. Sudireddy, J.T.S. Irvine, K. Thyden, J. Power Sources, 2017, 372, 99

[31] X. Zhou, N. Yan, K.T. Chuang, J. Luo, RSC Adv., 2014, 4, 118

[32] K.B. Yoo, G.M. Choi, Solid State Ionics, 2009, 180, 867

[33] K.B. Yoo, G.M. Choi, Solid State Ionics, 2011, 192, 515 
[34] C.D. Savaniu, D.N. Miller, J.T.S. Irvine, J. Am. Ceram. Soc., 2013, 96, 1718

[35] K. Lee, J. Kang, J. Lee, S. Lee, J. Bae, Int. J. Hydrogen Energy, 2018, 43, 3786

[36] L. Fan, Y. Xiong, Y. Wang, H. Kishimoto, K. Yamaji, T. Horita, J. Power Sources, $\mathbf{2 0 1 5}, 294,452$

[37] M.J. Lee, J.H. Shin, M.J. Ji, H.J. Hwang, J. Power Sources, 2018, 374, 181

[38] D.N. Miller, J.T.S. Irvine, J. Am. Ceram. Soc., 2011, 196, 7323

[39] D. Burnat, G. Nasdaurk, L. Holzer, M. Kopecki, A. Heel, J. Power Sources, 2018, 385,

62

[40] S.P. Jiang, J.G. Love, L. Apateanu, Solid State Ionics, 2003, 160, 15

[41] Z.H. Bi, J.H. Zhu, J. Electrochem. Soc., 2011, 158, B605

[42] V. Yurkiv, G. Constantin, A. Hornes, A. Gondolini, E. Mercadelli, A. Sanson, L.

Dessemond, R. Costa, J. Power Sources, 2015, 287, 58

[43] A.M. Dayaghi, K.J. Kim, S. Kim, J. Park, S.J. Kim, B.H. Park, G.M. Choi, J. Power Sources, 2016, 324, 288

[44] J.J. Gazzarri, O. Kesler, J. Power Sources, 2007, 167, 430

[45] M.C. Brant, T. Matencio, L. Dessemond, R.Z. Domingues, Solid State Ionics, 2006, 177,915

[46] L. Fan, Y. Xiang, L. Liu, Y. Wang, H. Kishimoto, K. Yamaji, T. Horita, J. Power Sources, 2014, 265, 125

[47] A.M. Dayaghi, K.J. Kim, S.J. Kim, S. Kim, H. Bae, G.M. Choi, J. Power Sources, 2017, 354,74

[48] V. Yurkiv, R.Costa, Z. Ilhan, A. Ansar, W.G. Bessler, J. Electrochem. Soc., 2014, 161,

F480

[49] Y. Yan, Q. Fang, L. Blum, W. Lehnert, Electrochim. Acta, 2017, 258, 1254

50] D. Papurello, D. Menechini, A. Lanzini, Electrochim. Acta, 2017, 258, 98 
[51] A. Bertei, G. Arcolini, J.P. Ouweltjes, Z. Wuillemin, P. Piccardo, C. Nicollela, Electrochim. Acta, 2016, 208, 189

[52] V. Yurkiv, G. Constantin, A. Gondolini, E. Mercadelli, A. Sanson, L. Dessemond, R. Costa, ECS Transactions, 2015, 68, 1517

[53] H. Yokokawa, H. Tu, B. Iwanschitz, A. Mai, J. Power Sources, 2008, 182, 400 


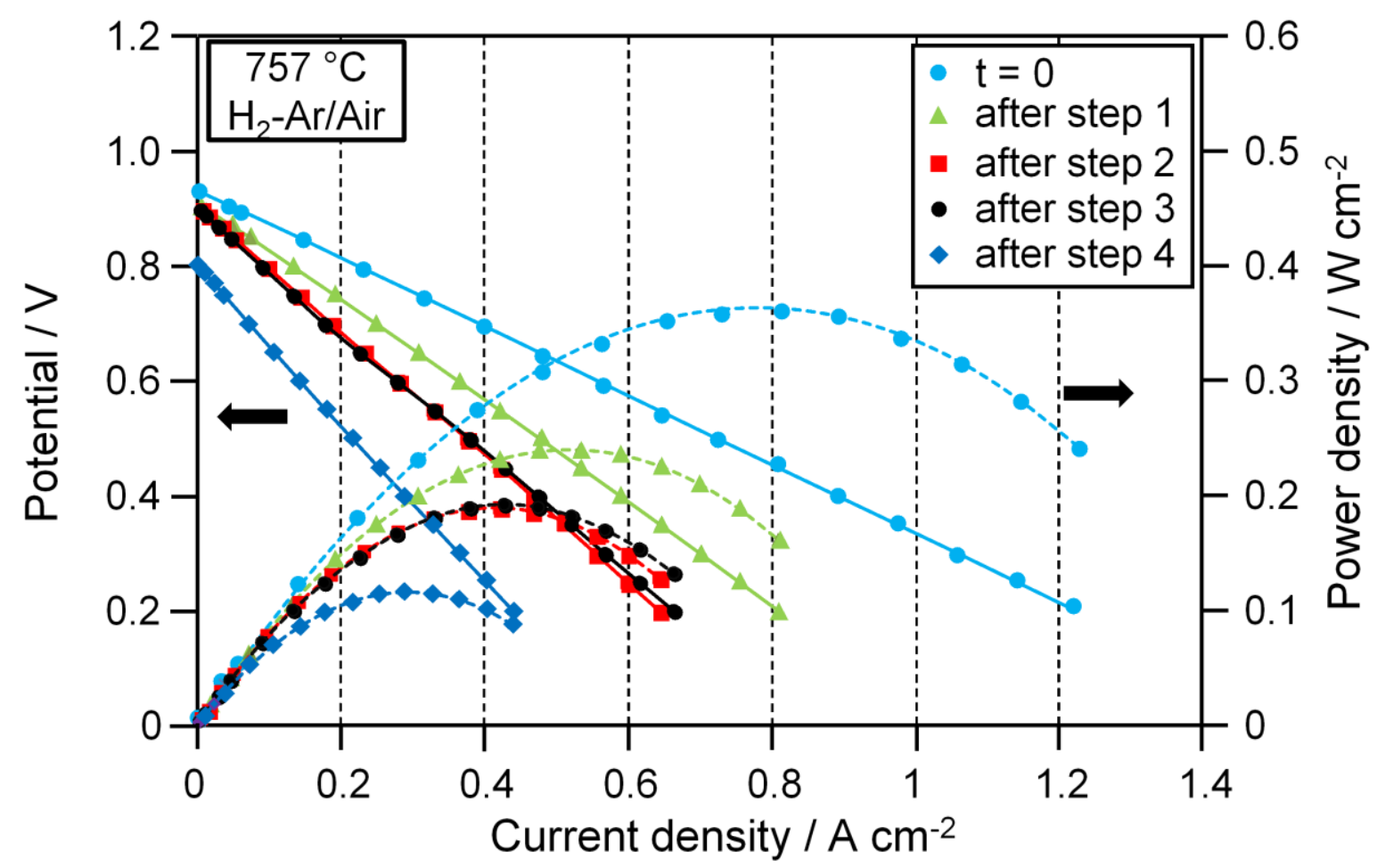

Figure 1: I-V-P curves of type A MSC at $757{ }^{\circ} \mathrm{C}\left(100 \mathrm{~mL} \mathrm{~min}^{-1}\right.$ air at the cathode side and $80 / 20 \mathrm{~mL} \mathrm{~min}^{-1}$ dry $\mathrm{H}_{2} / \mathrm{Ar}$ at the anode side). 


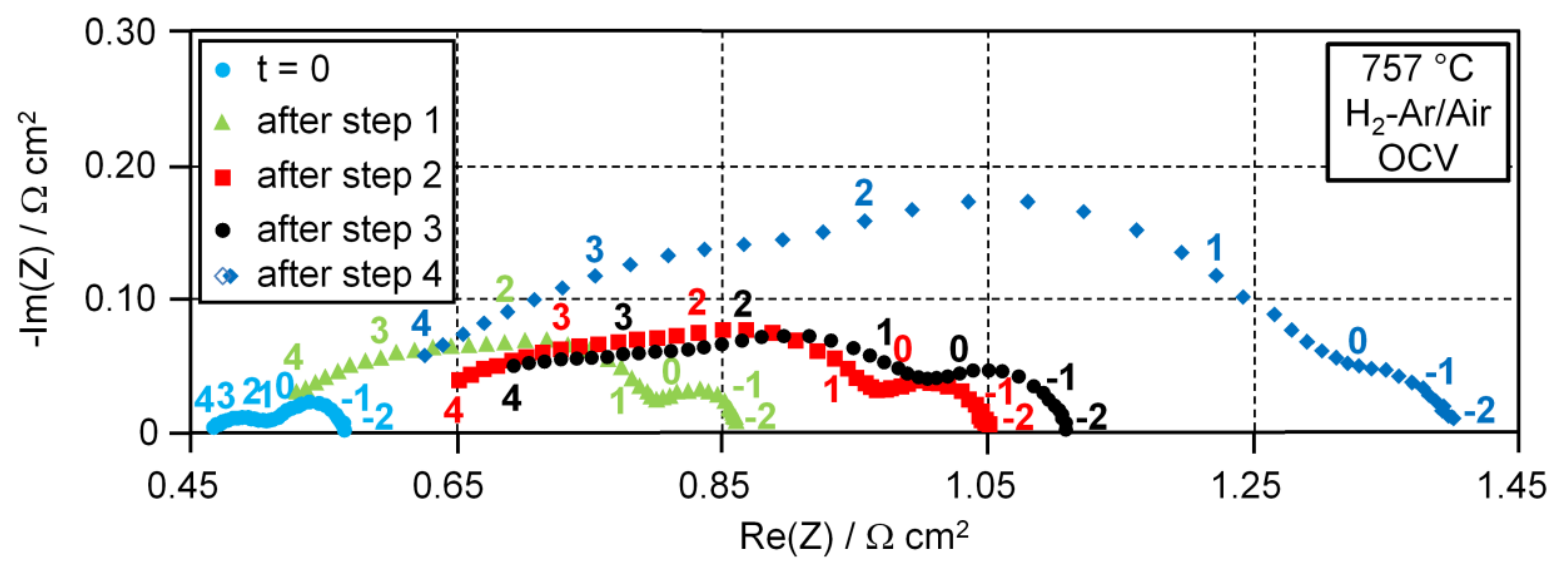

Figure 2: Impedance diagrams recorded at OCV on type A MSC before and after different steps at $757{ }^{\circ} \mathrm{C}\left(100 \mathrm{~mL} \mathrm{~min}^{-1}\right.$ air at the cathode side and $80 / 20 \mathrm{~mL} \mathrm{~min}^{-1}$ dry $\mathrm{H}_{2} / \mathrm{Ar}$ at the anode side). 

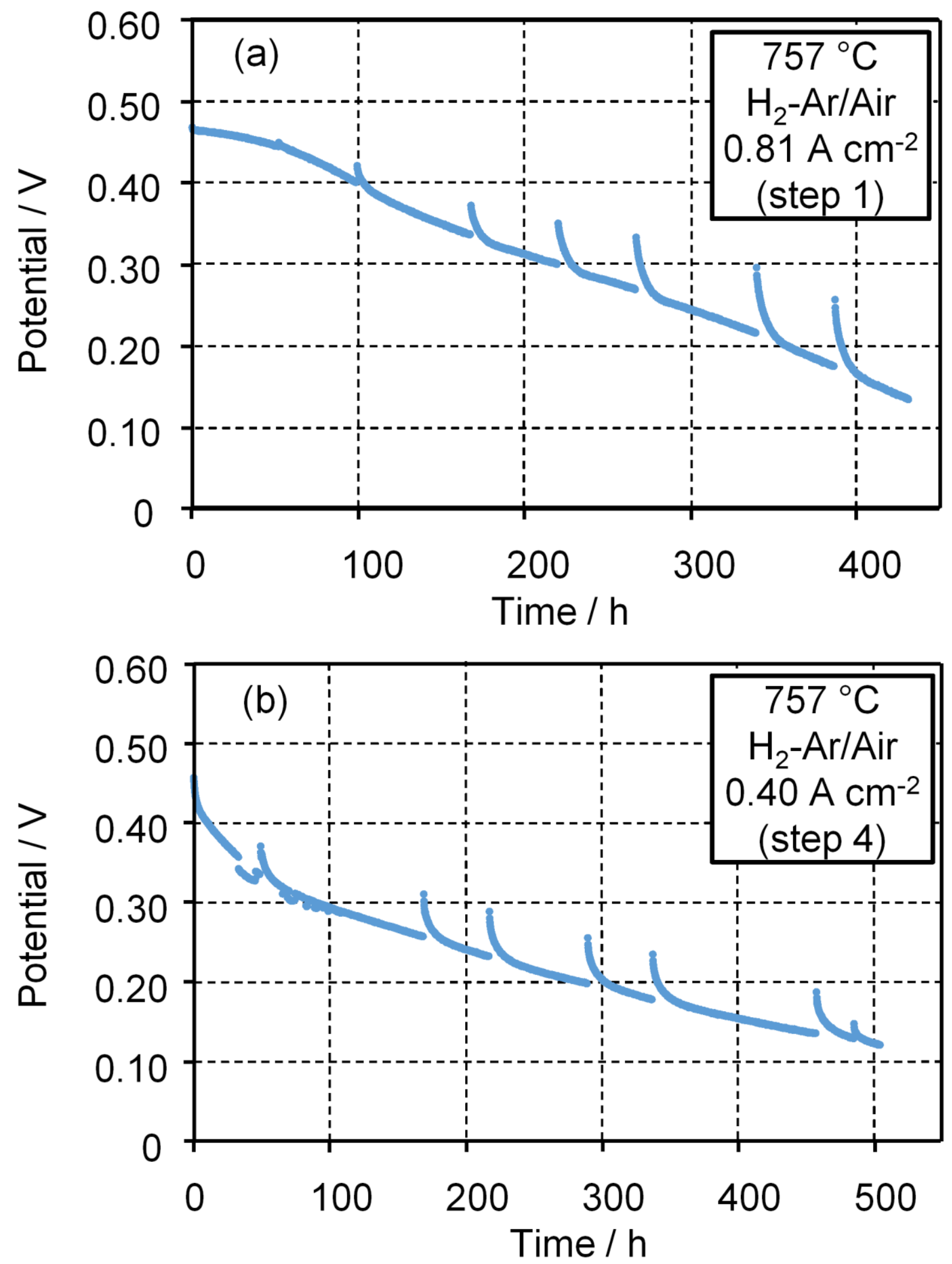

Figure 3: Cell potential recorded at (a) $0.81 \mathrm{~A} \mathrm{~cm}^{-2}$ and (b) $0.40 \mathrm{~A} \mathrm{~cm}^{-2}$ on type A MSC as a function of time at $757{ }^{\circ} \mathrm{C}\left(100 \mathrm{~mL} \mathrm{~min}^{-1}\right.$ air at the cathode side and $80 / 20 \mathrm{~mL} \mathrm{~min}{ }^{-1}$ dry $\mathrm{H}_{2} / \mathrm{Ar}$ at the anode side). 

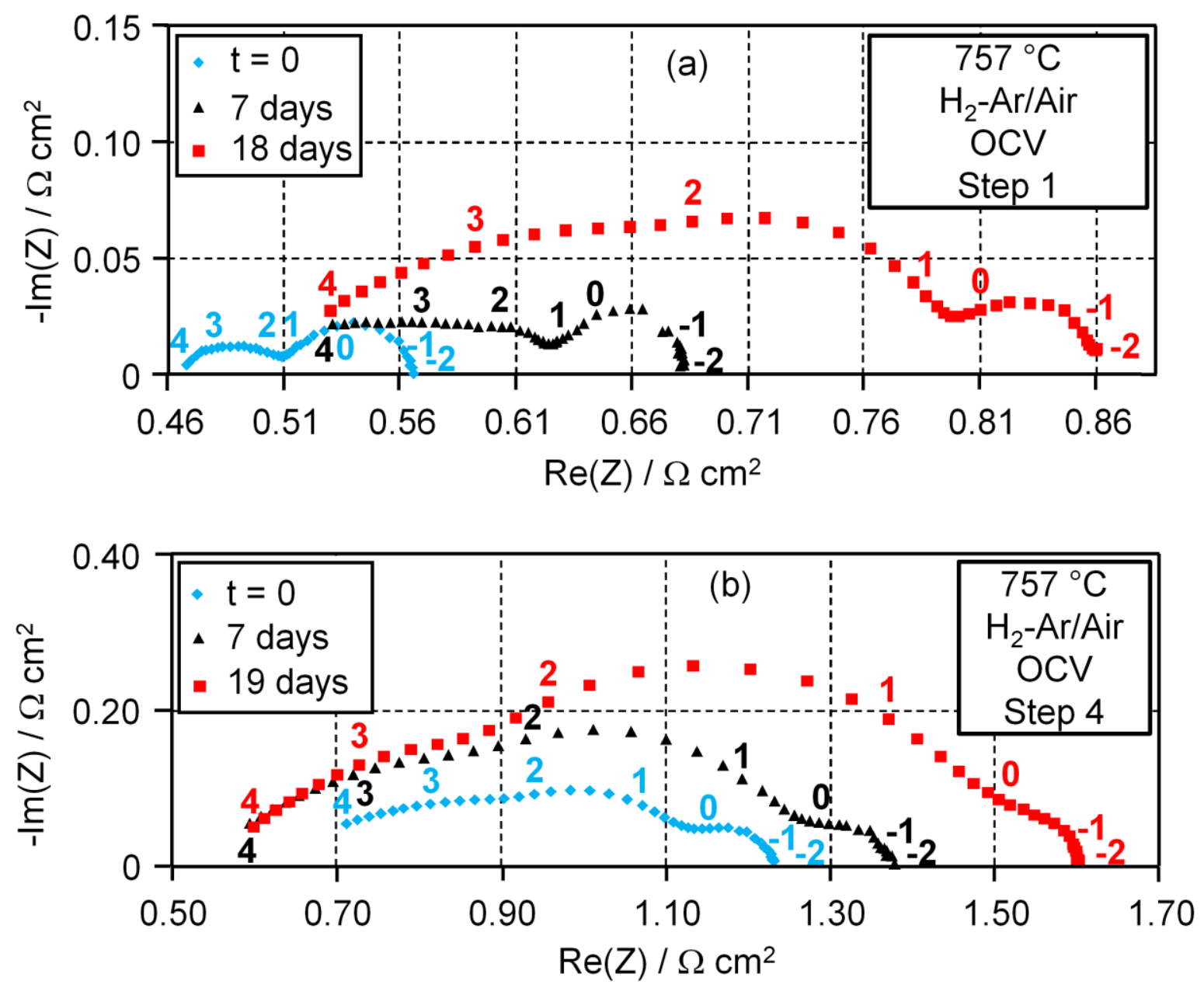

Figure 4: Impedance diagrams recorded at OCV on type A MSC before and after operation at (a) $0.81 \mathrm{~A} \mathrm{~cm}^{-2}$ and (b) at $0.40 \mathrm{~A} \mathrm{~cm}^{-2}$ at $757{ }^{\circ} \mathrm{C}\left(100 \mathrm{~mL} \mathrm{~min}^{-1}\right.$ air at the cathode side and $80 / 20 \mathrm{~mL} \mathrm{~min}^{-1}$ dry $\mathrm{H}_{2} / \mathrm{Ar}$ at the anode side). 


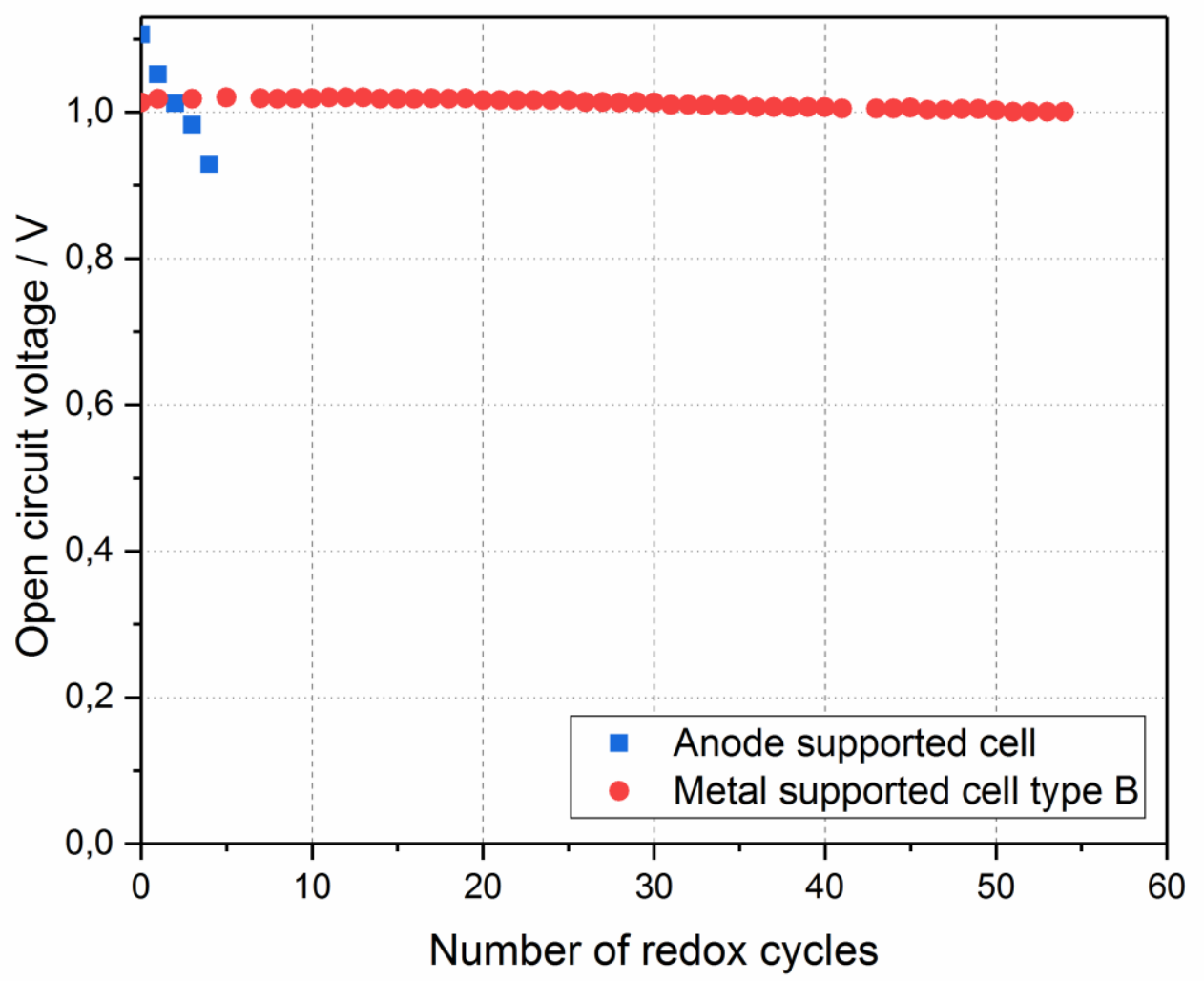

Figure 5: Evolutions of the OCV with the number of redox cycles at $750^{\circ} \mathrm{C}$ for ASC and type B MSC. $1 \mathrm{~L} \mathrm{~min}^{-1}$ of air was used at the cathode and $1 \mathrm{~L} \mathrm{~min}^{-1}$ of $\mathrm{H}_{2}-3 \% \mathrm{H}_{2} \mathrm{O}$ at the anode. 


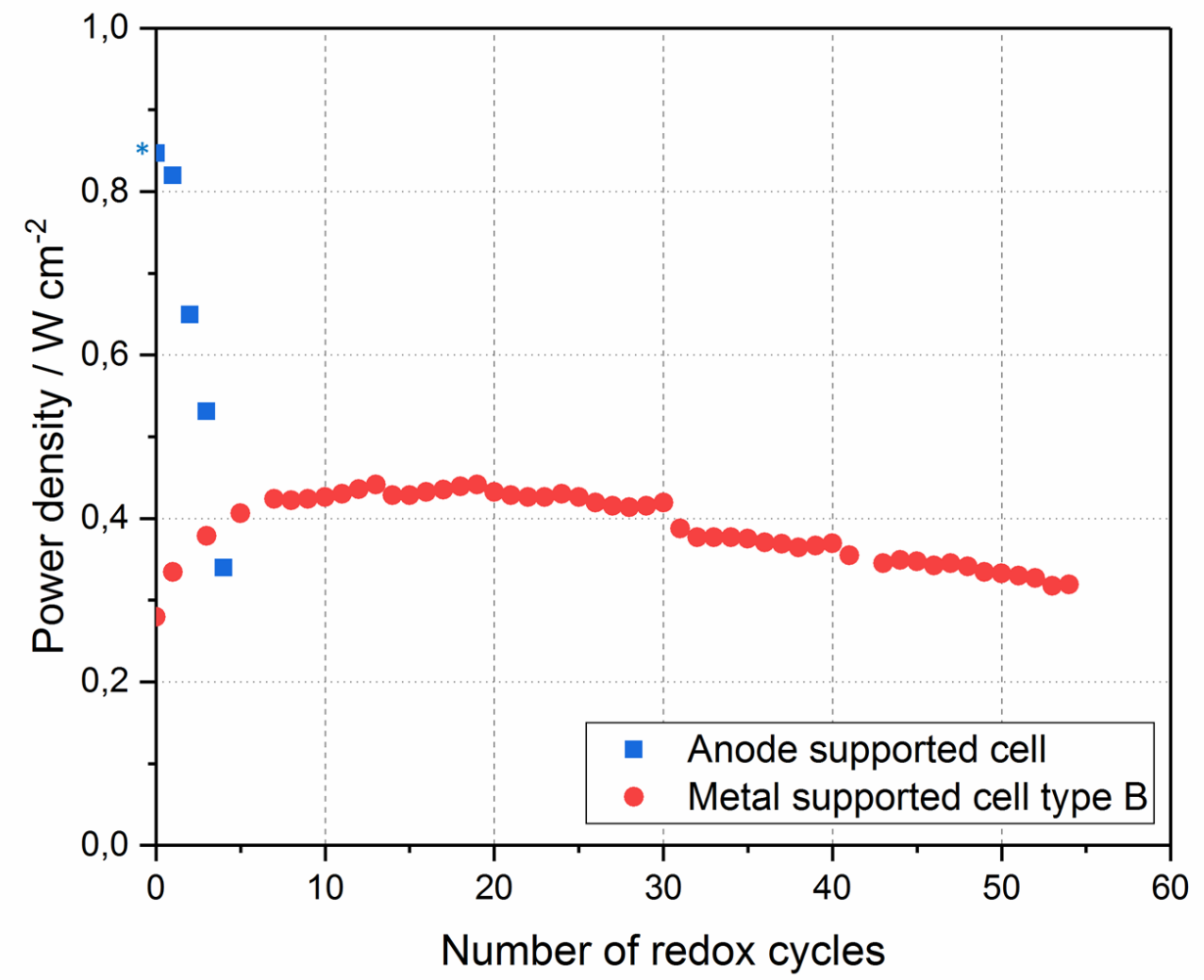

Figure 6: Evolution of the power density at $0.7 \mathrm{~V}$ with the number of redox cycles at $750^{\circ} \mathrm{C}$ for ASC and type B MSC. $1 \mathrm{~L} \mathrm{~min}^{-1}$ of air was used at the cathode and $1 \mathrm{~L} \mathrm{~min}^{-1}$ of $\mathrm{H}_{2}-3 \%$ $\mathrm{H}_{2} \mathrm{O}$ at the anode. * Power density at $0.751 \mathrm{~V}$. 


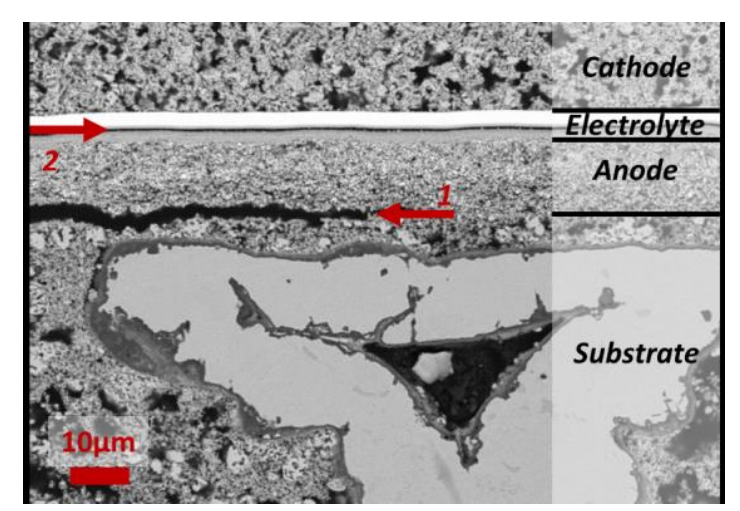

Figure 7: SEM cross section with annular back scattered electron detector recorded on the type B MSC showing cracks and delamination between the Anode functional layer and the substrate (denoted with the number 1), and between the gas tight PVD layer and the nanoporous supporting YSZ Layer (denoted with the number 2). 